\title{
Pulmonary outcomes in adults with a history of Bronchopulmonary Dysplasia differ from patients with asthma
}

Petra Um-Bergström ${ }^{1,3^{*}}$ (D) Jenny Hallberg ${ }^{1,4,5}$, Melvin Pourbazargan²,3, Eva Berggren-Broström, ${ }^{1,5}$ Giovanni Ferrara ${ }^{2,3}$, Maria J. Eriksson ${ }^{6,7}$, Sven Nyrén ${ }^{7,8}$, Jing Gao ${ }^{3}$, Gunnar Lilja ${ }^{1,5}$, Anders Lindén ${ }^{2,4}$, Åsa M. Wheelock ${ }^{3}$, Erik Melén ${ }^{1,4}$ and C. Magnus Sköld ${ }^{2,3}$

\begin{abstract}
Background: Bronchopulmonary dysplasia (BPD) is a risk factor for respiratory disease in adulthood. Despite the differences in underlying pathology, patients with a history of BPD are often treated as asthmatics. We hypothesized that pulmonary outcomes and health-related quality of life (HRQOL) were different in adults born preterm with and without a history of BPD compared to asthmatics and healthy individuals.

Methods: We evaluated 96 young adults from the LUNAPRE cohort (clinicaltrials.gov/ct2/show/NCT02923648), including 26 individuals born preterm with a history of BPD (BPD), 23 born preterm without BPD (preterm), 23 asthmatics and 24 healthy controls. Extensive lung function testing and HRQoL were assessed.

Results: The BPD group had more severe airway obstruction compared to the preterm-, $\left(\mathrm{FEV}_{1-} 0.94\right.$ vs. 0.28 $z$-scores; $p \leq 0.001)$; asthmatic- $(0.14 z$-scores, $p \leq 0.01)$ and healthy groups $(0.78 z$-scores, $p \leq 0.001)$. Further, they had increased ventilation inhomogeneity compared to the preterm- (LCl 6.97 vs. $6.73, p \leq 0.05)$, asthmatic- $(6.75$, $p=0.05)$ and healthy groups $(6.50 \mathrm{p} \leq 0.001)$. Both preterm groups had lower $\mathrm{D}_{\mathrm{LcO}}$ compared to healthy controls ( $p \leq 0.001$ for both). HRQoL showed less physical but more psychological symptoms in the BPD group compared to asthmatics.
\end{abstract}

Conclusions: Lung function impairment and HRQoL in adults with a history of BPD differed from that in asthmatics highlighting the need for objective assessment of lung health.

Keywords: Bronchopulmonary dysplasia, Adults, Astma, Lung function tests, Oscillometry, Spirometry, Multiple breath washout, HRLQoL

\section{Background}

In adults, chronic obstructive lung disease (COPD) caused by cigarette smoke [1] represent the vast majority of these patients. However, it has been acknowledged that $20-25 \%$ of all COPD patients have never smoked $[2,3]$. Other risk factors include asthma, recurrent respiratory infections, air pollution, biomass smoke and

\footnotetext{
* Correspondence: petra.um.bergstrom@ki.se

Data has previously been presented as abstracts at the Swedish Respiratory Society Annual Meeting, Linköping, April 2018 and at European Respiratory Society Annual Conference, Paris, September 2018.

'Sachs' Children and Youth Hospital, Department of Pediatrics, Södersjukhuset, 11883 Stockholm, Sweden

${ }^{3}$ Department of Medicine, Karolinska Institutet, Solna, Stockholm, Sweden Full list of author information is available at the end of the article
}

occupational exposures as well as dietary habits [4]. In addition, early life events have been shown to be associated with development of chronic airway obstruction [5]. Thus, preterm birth [6], low birth weight and restricted growth pattern [7, 8], maternal factors [9] and genetic predisposition have all been discussed in this context $[10,11]$. Infants born before gestational week 30 and with birth weight less than $1000 \mathrm{~g}$ are particularly vulnerable and approximately $10-30 \%$ of these children will develop bronchopulmonary dysplasia (BPD), a form of neonatal chronic lung disease [12]. Patients with BPD are often regarded as having asthma and are frequently treated with asthma medications without any scientific evidence for this assumption [13]. 
We hypothesized that adults born preterm, in particular those with a history of BPD, have a respiratory impairment that is different from what is observed in asthma, and that this significantly affects quality of life. To test this hypothesis, we examined in a cross-sectional setting never-smoking adults born preterm with and without a previous diagnosis of neonatal BPD and compared them to patients with asthma and healthy individuals. We thus aimed to characterize functional abnormalities in the airways and lung parenchyma and to correlate the findings to symptoms, quality of life and demographics.

\section{Methods}

\section{Participants}

We included four adult study groups: preterm born at gestational age $(\mathrm{GA}) \leq 32$ weeks with a neonatal diagnosis of BPD (BPD), preterm (born $\leq 32$ weeks) without BPD (preterm), patients (born $\geq 37$ weeks) with asthma according to GINA guidelines [14] (asthma) and healthy controls (born $\geq 37$ weeks) as part of the LUNAPRE (LUNg obstruction in Adulthood of PREmaturely born) study (clinicaltrials.gov/ct2/show/ NCT02923648).

The preterm born participants with and without a history of BPD were recruited from a pre-existing cohort [15] at the neonatal unit of Sachs' Children and Youth Hospital, Södersjukhuset, Stockholm, Sweden, where they were admitted in the neonatal ward between 1992 and 1998. Tracing and recruitment to LUNAPRE are detailed in Additional file 1: Figure S1. All participants provided written informed consent, and the study was approved by the regional ethics committee in Stockholm (ref: 201211872-31/4).

Between 2013 and 2017, patients and controls were invited to Department of Medicine Solna, Karolinska Institutet, Department of respiratory medicine and allergy, Karolinska University Hospital Solna, Stockholm, Sweden, and at Sachs' Children and Youth Hospital, Södersjukhuset, Stockholm.

The diagnosis of BPD was based on the need for supplemental oxygen for at least 28 days and severity degree determined at 36 weeks GA according to Jobe and Bancalari [16]. The diagnosis of allergic asthma [14] was confirmed by a positive methacholine challenge test with a decrease in $\mathrm{FEV}_{1} \geq 20 \%$ and presence of $\operatorname{IgE}$ sensitization to any airborne allergen (see below). None of the participants used inhaled corticosteroids, leukotriene receptor antagonists or antihistamines within 3 months prior to inclusion. The asthma group was not examined during pollen season. Information on perinatal and neonatal history was collected from the Swedish Medical Birth Registry and medical charts. This included information on maternal smoking during pregnancy, multiple birth, caesarean section, treatment with prenatal steroids, Apgar score, GA at birth, birth weight (BW), instillation of surfactant, number of days on a ventilator, Continuous Positive Airway Pressure and supplemental oxygen, Retinopathy of Prematurity (ROP) and Patent Ductus Arteriosus (PDA). Small for gestational age (SGA) was defined according to Marŝàl as -2SD [17].

Venous blood samples were drawn for analysis of white blood cell differential counts, C-reactive protein, alpha-1 antitrypsin, and an in vitro screening for IgE-sensitization towards airborne allergens, Phadiatop (Thermo Fisher Scientific; Pharmacia, Uppsala, Sweden). Phadiatop ${ }^{\circ}$ includes analysis of IgE-antibodies against birch, timothy, mugwort, cat, dog, horse dander, mold (Cladosporium herbarum), and house dust mite (Dermatophagoides pteronyssinus). Analyses were done at the clinical laboratory of Karolinska University Hospital, Solna, Sweden.

\section{Health-related quality of life and symptoms}

The validated Swedish version of the 36-item ShortForm Health Survey, first version (SF-36) [18] was used, a generic instrument for measuring health-related quality of life (HRQoL). Also, St George's Respiratory Questionnaire (SGRQ) [19] was employed, a disease specific 50-item questionnaire designed to measure impact on overall health, daily life, and perceived well-being in patients with obstructive airways disease. All participants also answered questions including environmental exposures, education, lifestyle, tobacco use, former and present health conditions, symptoms, and pharmacological treatment.

\section{Lung function testing}

Lung function testing was performed according to American Thoracic Society/European Respiratory Society guidelines [20-23]. Lung function testing included dynamic spirometry (Sensormedics 6200, SensorMedics, Yorba Linda, California, USA) where the highest values of forced expiratory volume in $1 \mathrm{~s}\left(\mathrm{FEV}_{1}\right)$ and forced vital capacity $(\mathrm{FVC})$, were extracted and $\mathrm{FEV}_{1} / \mathrm{FVC}$ ratio calculated and used for analysis. Whole body plethysmograph and diffusing capacity (Vmax62 J CareFusion, SensorMedics) provided information on residual volume (RV), vital capacity (VC), total lung capacity (TLC) and diffusing capacity of the lung for Carbon monoxide $\left(D_{\text {LCO }}\right)$. Methacholine challenge test (Spira nebulizer, Spira Elektro 2, Respiratory Care Centre, Hämeenlinna, Finland) was used to decide hyper-reactive airways. The mean value of frequency dependence of resistance $\left(R_{5-20}\right)$ and the square root of the area of reactance $\left(\mathrm{AX}^{0.5}\right)$ measured by impulse oscillometry (IOS) (Jaeger MasterScreenIOS system, Carefusion Technologies) were used for analysis. Mean values for lung clearance index (LCI) were extracted by Nitrogen dioxide multiple breath washout 
$\left(\mathrm{N}_{2} \mathrm{MBW}\right)$ (Exhalyzer ${ }^{\circ} \mathrm{D} \mathrm{N}_{2}$ MBWdevice, Eco Medics AG, Duernten, Switzerland). Fractional exhaled nitric oxide (FeNO) was measured (EcoMedics Exhalyzer ${ }^{\circ}$ CLD 88sp with Denox 88, Eco Medics, Duernten, Switzerland). In a few study subjects FeNO was measured using a NIOX device (Aerocrine AB, Solna, Sweden) [24]. Supplementary details on the lung function testing are provided in Additional file 2.

\section{Statistical analysis}

Demographic data are presented as median and range for continuous variables, or numbers and percentages for categorical variables. Due to non-normally distributed data, comparisons between groups were performed using the Wilcoxon rank-sum test for continuous variables. The Pearson's $X$-squared test was used for categorical outcomes. FVC, $\mathrm{FEV}_{1}$ and $\mathrm{FEV}_{1} / \mathrm{FVC}$ were converted to z-scores using the Global Lung Initiative reference values (GLI) [25]. Cross-sectional comparisons between groups were made using the Wilcoxon ranksum test. Associations between other lung function outcomes and the four groups were analyzed using linear regression on the median, adjusting for sex, height, and age when appropriate [26] . Correlations were assessed with Spearman's test. Correction for multiple testing was performed with false discovery rate by BenjaminiHochberg. $P$-values of $<0.05$ were considered statistically significant. Analyses were performed with the Stata 13.1 software package (StataCorp LP, College Station, TX, USA).

\section{Results}

\section{Participants}

Twenty-nine individuals in the BPD group and 28 individuals in the preterm group accepted participation in the study. Three subjects in the BPD group and five in the preterm group were excluded due to tobacco smoking resulting in a final inclusion of 26 and 23 individuals respectively. Only two subjects in the BPD group used inhaled corticosteroids prior to inclusion and these were included after a wash-out period of 3 months. The asthma group included 23 and the healthy control group 24 subjects. Participant characteristics are summarized in Table 1 . There was a significant $(p<0.001)$ lower proportion of individuals sensitized for IgE in the BPD group comparing to the preterm group. The asthma group had significantly $(p<0.001)$ higher blood eosinophil counts than did the other groups (Table 1).

Perinatal characteristics are summarized in Table 2. Subjects in the BPD group had lower GA and BW compared to preterm group $(p<0.001)$. The number of subjects born SGA was according to references in both BPD- and preterm groups [17]. Delivery by Caesarean section was more common in the groups of preterm born individuals, 78 and $50 \%$, respectively, in the preterm- and BPD groups ( $p=0.043$ compared to healthy controls). There was a significantly higher proportion of individuals treated for PDA and having septicemia during the neonatal period in the BPD group compared to the preterm group (Table 2). The included subjects in the BPD- and preterm groups did not differ in BW, GA and SGA from the corresponding groups in the whole original cohort [15] except the BPD group who had 4 days lower mean GA.

\section{Health-related quality of life and symptoms}

The physical component summary (PCS) scores of SF36 showed no significant difference between healthy controls and the BPD group, but both preterm- and asthma groups reported lower scores $(p<0.01$ and $p<0.05)$ than the healthy controls. Both BPD- and preterm groups reported decreased mental component summery (MCS) scores (Fig. 1a and b; Additional file 3: Table S1).

The asthma group had significant higher total score in SGRQ $(p<0.001)$ compared to the healthy controls, BPD- and preterm groups. There were no significant differences between BPD-, preterm groups and healthy controls (Fig. 1c; Additional file 3: Table S1).

The asthma group reported more wheeze and cough than the other groups. It was more common in the BPDand asthma groups to have phlegm that was difficult to expectorate compared to the healthy controls. There were no significant differences between the groups in frequency of pneumonia, hours of physical activities or sleeping hours. The asthma group spent less time in front of a screen (TV, computer) (Additional file 3: Table S1).

\section{Lung function}

The BPD group had a decreased $\mathrm{FEV}_{1}, \mathrm{FVC}$ and $\mathrm{FEV}_{1} /$ FVC ratio compared to the other groups. The asthma group had decreased $\mathrm{FEV}_{1}, \mathrm{FVC}$ and $\mathrm{FEV}_{1} / \mathrm{FVC}$ ratio compared to healthy controls and the preterm group (Table 3; Fig. 2a and b). Twenty percent of the BPD group were reversible to bronchodilator whereas 11\% were reversible in the preterm- and $14 \%$ in asthmagroups. There were no statistically significant differences in reversibility between the BPD- and the asthma groups (Table 3). In the BPD group, $27 \%$ had a $\mathrm{FEV}_{1} / \mathrm{FVC}$ ratio below lower limit of normal $(\leq-1.64 \mathrm{z}$-scores). The corresponding percentage in the preterm- and in the asthma groups was 4.6 and $4.6 \%$ respectively (Table 4).

The BPD group had significantly lower lung volumes than the other groups (Table 3). Both TLC and VC were decreased $(p<0.05$ and $p<0.01)$ although no significant differences were observed when comparing the ratio between the RV and TLC. 
Table 1 Characteristics of study participants

\begin{tabular}{|c|c|c|c|c|}
\hline & $\begin{array}{l}\mathrm{BPD} \\
n=26\end{array}$ & $\begin{array}{l}\text { Preterm } \\
n=23\end{array}$ & $\begin{array}{l}\text { Asthma } \\
n=23\end{array}$ & $\begin{array}{l}\text { Healthy controls } \\
n=24\end{array}$ \\
\hline Sex, Male/Female & $11 / 15$ & $10 / 13$ & $10 / 13$ & $12 / 12$ \\
\hline Age, years & $\begin{array}{l}19.6^{*} \\
(18.2 ; 21.2)\end{array}$ & $\begin{array}{l}19.1^{* *} \\
(18.3 ; 22.4)\end{array}$ & $\begin{array}{l}20.2 \\
(18.6 ; 23.3)\end{array}$ & $\begin{array}{l}20.5 \\
(18.3 ; 23.8)\end{array}$ \\
\hline Weight, kg M/F & $\begin{array}{l}69.6 / 61.5 \\
(48 ; 109.9) /(44.5 ; 88)\end{array}$ & $\begin{array}{l}68 / 59.2 \\
(55 ; 85.5) /(44 ; 72.4)\end{array}$ & $\begin{array}{l}75.7 / 59 \\
(62 ; 89) /(48 ; 106)\end{array}$ & $\begin{array}{l}71.8 / 62 \\
(56.5 ; 117.4) /(44.8 ; 112)\end{array}$ \\
\hline Length, $\mathrm{cm} \mathrm{M/F}$ & $\begin{array}{l}175 / 166 \\
(155 ; 192) /(155 ; 173)\end{array}$ & $\begin{array}{l}182 / 165 \\
(169 ; 192) /(152 ; 173)\end{array}$ & $\begin{array}{l}174 / 168 \\
(164 ; 182) /(150 ; 176)\end{array}$ & $\begin{array}{l}180 / 167 \\
(168 ; 194) /(151 ; 190)\end{array}$ \\
\hline $\mathrm{BMI}, \mathrm{m} / \mathrm{kg}^{2} \mathrm{M} / \mathrm{F}$ & $\begin{array}{l}20 / 22 \\
(18 ; 30) /(18 ; 32)\end{array}$ & $\begin{array}{l}20 / 21 \\
(17 ; 28) /(17 ; 28)\end{array}$ & $\begin{array}{l}24 / 21 \\
(21 ; 29) /(18 ; 34)\end{array}$ & $\begin{array}{l}21.5 / 22 \\
(20 ; 33) /(18 ; 38)\end{array}$ \\
\hline FeNO, ppb & $\begin{array}{l}14.9 \\
(9.2 ; 22.2)\end{array}$ & $\begin{array}{l}13.1 \\
(11 ; 19.8)\end{array}$ & $\begin{array}{l}31.4^{* *} \\
(11.6 ; 49.2)\end{array}$ & $\begin{array}{l}10.9 \\
(9.7 ; 17.1)\end{array}$ \\
\hline Positive Phadiatop & $3(12)$ & $8(35)$ & $23(100)$ & 0 \\
\hline Blood Eosinophils $1 \times 10^{2} / \mu \mathrm{L}$ & $\begin{array}{l}0.1 \\
(0.0 ; 0.3)\end{array}$ & $\begin{array}{l}0.0 \\
(0.0 ; 0.2)\end{array}$ & $\begin{array}{l}0.3^{* * *} \\
(0.0 ; 0.7)\end{array}$ & $\begin{array}{l}0.0 \\
(0.0 ; 0.5)\end{array}$ \\
\hline $\mathrm{CRP}, \mathrm{mg} / \mathrm{L}$ & $\begin{array}{l}0.35 \\
(0 ; 2.1)\end{array}$ & $\begin{array}{l}0.32 \\
(0 ; 1.3)\end{array}$ & $\begin{array}{l}0.46 \\
(0 ; 7.6)\end{array}$ & $\begin{array}{l}0.34 \\
(0 ; 7.7)\end{array}$ \\
\hline Alpha-1 antitrypsin g/L & $\begin{array}{l}1.4 \\
(0.8 ; 1.7)\end{array}$ & $\begin{array}{l}1.3 \\
(1.0 ; 1.7)\end{array}$ & $\begin{array}{l}1.4 \\
(1.1 ; 1.8)\end{array}$ & $\begin{array}{l}1.4 \\
(1.1 ; 1.9)\end{array}$ \\
\hline Antidepressant medication & $1(3.8)$ & $2(8.7)$ & $2(8.7)$ & $1(4.1)$ \\
\hline ADHD/ADD medication & $3(11.5)$ & $3(13)$ & 0 & $1(4.1)$ \\
\hline
\end{tabular}

Data are presented as median (range) or numbers (\%). Abbreviations: $B P D$ bronchopulmonary dysplasia, $M$ male, $F$ female, $B M I$ body mass index, FeNO fractional exhaled nitric oxide, CRP C-reactive protein, $A D H D$ Attention deficit hyperactivity disorder, $A D D$ Attention deficit disorder

${ }^{*} p \leq 0.05,{ }^{* *} p \leq 0.01,{ }^{* * *} p \leq 0.001$ (compared to healthy)

Table 2 Perinatal characteristics of study participants

\begin{tabular}{|c|c|c|c|c|}
\hline & $\begin{array}{l}\text { BPD } \\
n=26\end{array}$ & $\begin{array}{l}\text { Preterm } \\
n=23\end{array}$ & $\begin{array}{l}\text { Asthma } \\
n=23\end{array}$ & $\begin{array}{l}\text { Healthy controls } \\
n=24\end{array}$ \\
\hline Male/Female & $11 / 15$ & $10 / 13$ & $10 / 13$ & $12 / 12$ \\
\hline Gestational age at birth, weeks & $\begin{array}{l}26^{\# \#} \\
(24-31)\end{array}$ & $\begin{array}{l}29.5 \\
(26-32)\end{array}$ & $\begin{array}{l}40 \\
(38-42)\end{array}$ & $\begin{array}{l}40 \\
(37-43)\end{array}$ \\
\hline Birth weight, g & $\begin{array}{l}960^{\# \# \#} \\
(583-1510)\end{array}$ & $\begin{array}{l}1470 \\
(659-2200)\end{array}$ & $\begin{array}{l}3505 \\
(2660-4840)\end{array}$ & $\begin{array}{l}3458 \\
(2670-4550)\end{array}$ \\
\hline Small for gestational age & $8(31)$ & $7(30)$ & 0 & 0 \\
\hline Maternal smoking during pregnancy & $7(27)$ & $3(13)$ & $2(9)$ & $5(21)$ \\
\hline Prenatal corticosteroid therapy & $11(42)$ & $10(43)$ & N/A & N/A \\
\hline Caesarean section & $13(50)$ & $18(78)$ & $1(4)$ & $1(4)$ \\
\hline Multiple birth & $8(31)$ & $12(52)$ & 0 & 0 \\
\hline Apgar score at $1 \mathrm{~min}$ & $5(1-9)^{* * *}$ & $8(4-10)$ & $9(5-10)$ & $9(5-9)$ \\
\hline Apgar score at $5 \mathrm{~min}$ & $7(3-10)^{* * *}$ & $9(3-10)^{* *}$ & $10(7-10)$ & $10(8-10)$ \\
\hline Instillation of surfactant & $8(31)$ & $2(4)$ & N/A & N/A \\
\hline Ventilator therapy, days & $4(0-38)$ & $0(0-8)$ & N/A & N/A \\
\hline CPAP, days & $41(3-70)$ & $3(0-19)$ & $\mathrm{N} / \mathrm{A}$ & N/A \\
\hline Supplemental $\mathrm{O}_{2}$, days & $67(28-180)$ & $3(1-26)$ & N/A & N/A \\
\hline Septicemia & $16(62)^{\# \#}$ & $6(26)$ & $\mathrm{N} / \mathrm{A}$ & N/A \\
\hline PDA, treated & $8(31)^{\# \#}$ & 0 & N/A & N/A \\
\hline ROP grade 3-4 & $7(27)$ & $3(13)$ & N/A & N/A \\
\hline
\end{tabular}

Data are presented as median (range) or numbers (\%). Abbreviations: BPD bronchopulmonary dysplasia, N/A not applicable, CPAP continuous positive airway pressure, $P D A$ patent ductus arteriosus, $R O P$ retinopathy of prematurity

${ }^{\# \#} p \leq 0.01 ;{ }^{\# \#} p \leq 0.001$ (BPD versus preterm)

${ }^{* *} p \leq 0.01$; ${ }^{* * *} p \leq 0.001$ (Comparing BPD-, preterm- and asthma-groups to healthy controls) 


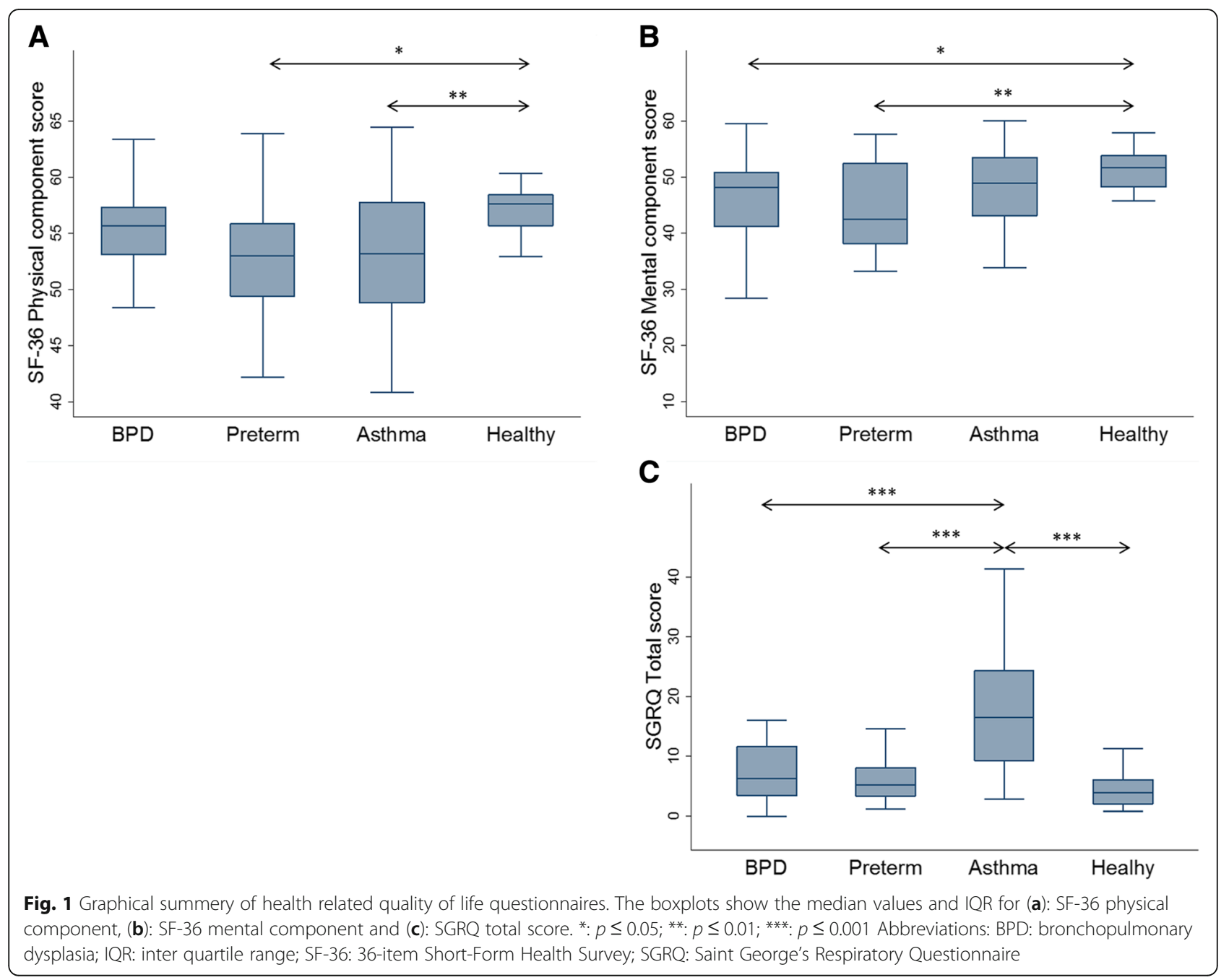

Both the BPD- and the preterm groups had decreased $\mathrm{D}_{\mathrm{LCO}}$ compared to healthy controls $(p<0.001$, Table 3, Fig. 2c). Seventy-three percent of the BPD group and $56 \%$ of the preterm group were positive in methacholine challenge test (Table 3). By study design, everyone in the asthma group and none of the healthy controls had a positive methacholine challenge test.

Impulse oscillometry showed no significant differences when comparing $\mathrm{R}_{5-20}$ and $\mathrm{AX}^{0.5}$ between the four groups (Table 3). In the BPD group LCI was significantly $(p<0.001)$ higher compared to the other groups (Table 3; Fig. 2d), but there were no statistically significant differences between preterm-, asthma groups and healthy controls. Thirty-two percent of the participants in the BPD group had LCI measures above lower limit of normal $(\leq-1.64 \mathrm{z}$-scores). The corresponding percentage in the preterm group was $8.7 \%$, in the asthma group $17 \%$ and in healthy controls $4.6 \%$ (Table 4 ).

\section{Correlations between lung function, perinatal} characteristics, HRQoL and symptoms

Within the BPD- and preterm groups we found no statistically significant associations between $\mathrm{FEV}_{1}, \mathrm{FVC}$, $\mathrm{FEV}_{1} / \mathrm{FVC}$ ratio, TLC, VC, RV, $\mathrm{D}_{\mathrm{LCO}}, \mathrm{LCI}, \mathrm{R}_{5-20}$, and AX to GA, BW or SGA. We could not show any statistically significant correlations between scores in SGRQ and SF-36 or symptoms and lung function measures in this study.

\section{Discussion}

This study demonstrates that adults born preterm with a prior neonatal diagnosis of BPD display signs of obstructive and restrictive lung function impairment together with gas diffusion disturbance. The lung function impairment included involvement of small airways and was different from that of asthmatics. Despite more airway obstruction from a quantitative point-of-view, the individuals in the BPD group reported less symptoms and less impact on quality of life than the asthma group. 
Table 3 Lung function in each study group

\begin{tabular}{|c|c|c|c|c|}
\hline & $\begin{array}{l}\text { BPD } \\
n=26\end{array}$ & $\begin{array}{l}\text { Preterm } \\
n=23\end{array}$ & $\begin{array}{l}\text { Asthma } \\
n=23\end{array}$ & $\begin{array}{l}\text { Healthy controls } \\
n=24\end{array}$ \\
\hline $\mathrm{FEV}_{1} z_{\text {-scores }}{ }^{\mathrm{a}}$ & $\begin{array}{l}-0.94^{* * *} \\
(-1.57 ;-0.08)\end{array}$ & $\begin{array}{l}0.28 \\
(-0.27 ; 1.18)\end{array}$ & $\begin{array}{l}0.14 \\
(-0.52 ; 0.77)\end{array}$ & $\begin{array}{l}0.78 \\
(-0.03 ; 1.26)\end{array}$ \\
\hline $\mathrm{FEV}_{1} \%$ pred. ${ }^{\mathrm{a}}$ & $\begin{array}{l}88.9^{* * *} \\
(81.4 ; 99.1)\end{array}$ & $\begin{array}{l}103.3 \\
(96.9 ; 113.3)\end{array}$ & $\begin{array}{l}101.7 \\
(94.1 ; 109.0)\end{array}$ & $\begin{array}{l}108.9 \\
(99.7 ; 114.1)\end{array}$ \\
\hline FVC $z$-scores ${ }^{a}$ & $\begin{array}{l}-0.32^{*} \\
(-1.24 ; 0.14)\end{array}$ & $\begin{array}{l}-0.26 \\
(-0.64 ; 0.60)\end{array}$ & $\begin{array}{l}0.13 \\
(-0.48 ; 0.85)\end{array}$ & $\begin{array}{l}0.37 \\
(-0.18 ; 0.85)\end{array}$ \\
\hline FVC \% pred. ${ }^{a}$ & $\begin{array}{l}96^{*} \\
(85.6 ; 101.7)\end{array}$ & $\begin{array}{l}96.9 \\
(92.2 ; 107.5)\end{array}$ & $\begin{array}{l}101.6 \\
(94.5 ; 110.4)\end{array}$ & $\begin{array}{l}104.6 \\
(97.9 ; 109.8)\end{array}$ \\
\hline $\mathrm{FEV}_{1} / \mathrm{FVC}^{\mathrm{b}}$ & $\begin{array}{l}0.82^{* * *} \\
(0.79 ; 0.85)\end{array}$ & $\begin{array}{l}0.91 \\
(0.87 ; 0.94)\end{array}$ & $\begin{array}{l}0.86 \\
(0.83 ; 0.89)\end{array}$ & $\begin{array}{l}0.90 \\
(0.87 ; 0.93)\end{array}$ \\
\hline $\begin{array}{l}\mathrm{FEV}_{1} / \mathrm{FVC} \\
z \text {-scores }^{\mathrm{a}}\end{array}$ & $\begin{array}{l}-0.67^{* * *} \\
(-1.86 ; 0.18)\end{array}$ & $\begin{array}{l}0.82 \\
(0.13 ; 1.33)\end{array}$ & $\begin{array}{l}-0.20^{*} \\
(-0.43 ; 0.33)\end{array}$ & $\begin{array}{l}0.42 \\
(-0.26 ; 0.89)\end{array}$ \\
\hline Reversibility \% & $\begin{array}{l}6.9 \\
(3.3 ; 10.9)\end{array}$ & $\begin{array}{l}3.7 \\
(1.4 ; 7.6)\end{array}$ & $\begin{array}{l}5.9 \\
(3.7 ; 8.3)\end{array}$ & $\begin{array}{l}4.3 \\
(1.9 ; 6.2)\end{array}$ \\
\hline Methacholine challenge pos. & $19(73)$ & $13(56)$ & $23(100)$ & 0 \\
\hline TLC \% pred. ${ }^{a}$ & $\begin{array}{l}95^{*} \\
(87.5 ; 101.5)\end{array}$ & $\begin{array}{l}97 \\
(92 ; 114)\end{array}$ & $\begin{array}{l}99 \\
(95 ; 106)\end{array}$ & $\begin{array}{l}104 \\
(95.5 ; 108)\end{array}$ \\
\hline $\mathrm{RV} \%$ pred. ${ }^{\mathrm{a}}$ & $\begin{array}{l}88 \\
(60.5 ; 99.5)\end{array}$ & $\begin{array}{l}79 \\
(65 ; 132)\end{array}$ & $\begin{array}{l}72.5 \\
(52 ; 96)\end{array}$ & $\begin{array}{l}84.5 \\
(68.5 ; 105.5)\end{array}$ \\
\hline VC \% pred. ${ }^{a}$ & $\begin{array}{l}96.5^{* *} \\
(88 ; 106)\end{array}$ & $\begin{array}{l}103 \\
(96 ; 110)\end{array}$ & $\begin{array}{l}106 \\
(99 ; 113)\end{array}$ & $\begin{array}{l}107 \\
(100.5 ; 115.5)\end{array}$ \\
\hline $\mathrm{RV} / \mathrm{TLC}$ & $\begin{array}{l}20 \\
(17 ; 24.5)\end{array}$ & $\begin{array}{l}20.5 \\
(17.5 ; 22.5)\end{array}$ & $\begin{array}{l}18.5 \\
(14 ; 23)\end{array}$ & $\begin{array}{l}19 \\
(17 ; 22.5)\end{array}$ \\
\hline $\mathrm{D}_{\mathrm{LCO} \text { adj }} \%$ pred. $^{\mathrm{a}}$ & $\begin{array}{l}67^{* * *} \\
(64 ; 73)\end{array}$ & $\begin{array}{l}73^{* * *} \\
(65 ; 83)\end{array}$ & $\begin{array}{l}81.5 \\
(75 ; 91)\end{array}$ & $\begin{array}{l}86.5 \\
(80 ; 96)\end{array}$ \\
\hline $\mathrm{LCl}^{\mathrm{a}}$ & $\begin{array}{l}6.97^{* * *} \\
(6.84 ; 7.72)\end{array}$ & $\begin{array}{l}6.73 \\
(6.29 ; 7.12)\end{array}$ & $\begin{array}{l}6.75 \\
(6.37 ; 7.08)\end{array}$ & $\begin{array}{l}6.50 \\
(6.31 ; 6.72)\end{array}$ \\
\hline $\begin{array}{l}\mathrm{R}_{5-20} \\
(\mathrm{kPa} / \mathrm{L} / \mathrm{sec})^{\mathrm{b}}\end{array}$ & $\begin{array}{l}0.014 \\
(-0.002 ; 0.030)\end{array}$ & $\begin{array}{l}0.021 \\
(0.003 ; 0.039)\end{array}$ & $\begin{array}{l}0.015 \\
(-0.003 ; 0.033)\end{array}$ & $\begin{array}{l}0.007 \\
(-0.010 ; 0.024)\end{array}$ \\
\hline $\begin{array}{l}\mathrm{AX} 0.5 \\
(\mathrm{kPa} / \mathrm{L})^{\mathrm{b}}\end{array}$ & $\begin{array}{l}0.156 \\
(0.120 ; 0.192)\end{array}$ & $\begin{array}{l}0.163 \\
(0.123 ; 0.202)\end{array}$ & $\begin{array}{l}0.140 \\
(0.099 ; 0.181)\end{array}$ & $\begin{array}{l}0.125 \\
(0.086 ; 0.164)\end{array}$ \\
\hline
\end{tabular}

BPD-, Preterm- and asthma- groups were compared to healthy controls. Data are presented as median (IQR) numbers (\%). All dynamic spirometry measures (FEV ${ }_{1}$, FVC, $\left.F E V_{1} / F V C\right)$ and the impulse oscillometry data $\left(R_{5-20}, A X\right)$ are post bronchodilator (four doses of salbutamol $0.1 \mathrm{mg} /$ dose) measures

${ }^{\mathrm{a}}$ Analysis with quantile regression on median

${ }^{b}$ Analysis with quantile regression on median adjusting for age, sex and height

${ }^{*} p \leq 0.05 ;{ }^{* *} p \leq 0.01$; ${ }^{* * *} p \leq 0.001$, comparing BPD-, preterm- and asthma-groups to healthy controls

Abbreviations: $B P D$ bronchopulmonary dysplasia, $F E V$, forced expiratory volume in $1 \mathrm{~s}, F V C$ forced vital capacity, $T L C$ total lung capacity, $R V$ residual volume,

$V C$ vital capacity, $D_{L C O}$ adj diffusing capacity of the lung for Carbon monoxide adjusted for blood haemoglobin, $L C I$ lung clearance index, $R_{5-20}$ resistance

at $5-20 \mathrm{~Hz}, A X^{0.5}$ square root of the area of reactance, IQR Inter quartile range

We were also able to demonstrate that preterm born young adults without prior neonatal diagnosis of BPD were normal in their lung function despite a disturbance of gas diffusion. Finally, both preterm groups, in particular those with a history of BPD had a high incidence of bronchial hyper-reactivity.

Bronchopulmonary dysplasia is a common cause of respiratory disease in children born preterm. The condition is often interpreted as a developmental disorder with pathogenesis being linked to underdeveloped lungs, inflammation, baro- and volutrauma resulting from mechanical ventilation and oxidative stress due to oxygen treatment [27]. Northway et al. [28] characterized "old" BPD by inflammation, airway smooth muscle hypertrophy, emphysema, and parenchymal fibrosis caused by high oxygen concentration and high ventilation pressures. The "new" BPD is characterized by even more immature lung tissue affected by reparative processes, impaired alveolarization, and dysmorphic vascular growth [29]. Obstructive airway impairments have previously been demonstrated in children [15], adolescents [30] and adults [31] born preterm with BPD $[32,33]$. To identify preterm born patients at risk for developing chronic lung disease in adulthood is however difficult due to the lack of specific disease markers. We aimed to study pulmonary outcomes in young adults born preterm with and without a history of BPD and compare to asthmatics and healthy controls. In order to rule out 


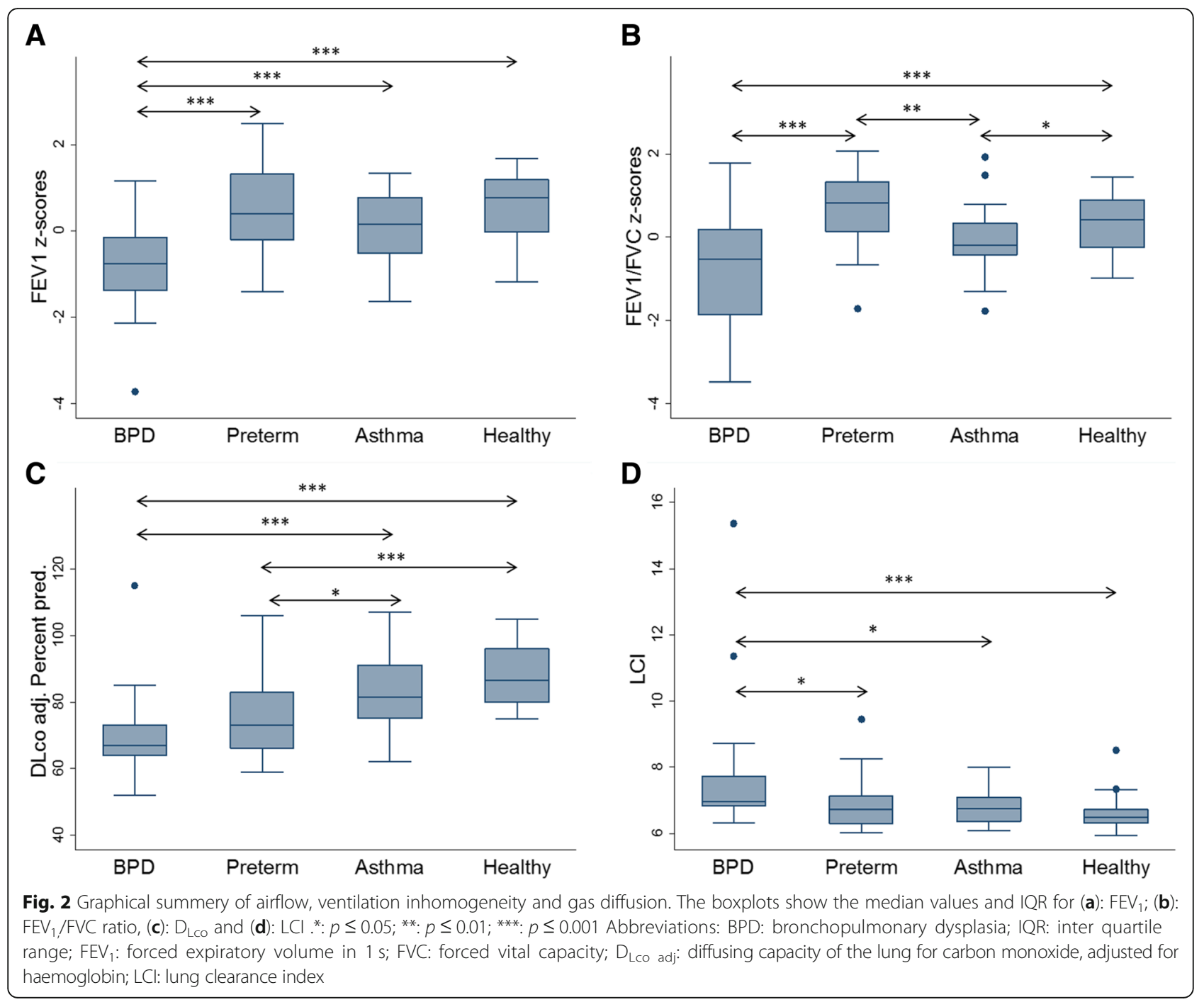

potential effects from smoking and ongoing medication, we choose to only include never-smokers and to perform the clinical investigation when the study subjects had been without any anti-inflammatory treatment for at least 3 months. No subjects were excluded due to the criterion of being without anti-inflammatory treatment. We do not

Table 4 Proportion of subjects in each group with spirometry and multiple breath wash-out measures below -1.64 z-scores

\begin{tabular}{lllll}
\hline & $\begin{array}{l}\text { BPD } \\
n=26\end{array}$ & $\begin{array}{l}\text { Preterm } \\
n=23\end{array}$ & $\begin{array}{l}\text { Asthma } \\
n=23\end{array}$ & $\begin{array}{l}\text { Healthy controls } \\
n=24\end{array}$ \\
\hline FEV $_{1}$ z-scores & $5(19)^{*}$ & 0 & 0 & 0 \\
FVC $z$-scores & 0 & $1(4.3)$ & 0 & 0 \\
FEV $_{1} /$ FVC $z$-scores & $7(27)^{* *}$ & $1(4.3)$ & $1(4.3)$ & 0 \\
LCl z-scores $^{*}$ & $8(32)^{* * *}$ & $2(8.7)$ & $4(17)$ & $1(4.6)$ \\
\hline
\end{tabular}

BPD-, preterm- and asthma-groups were compared to healthy controls. Data are presented as numbers (\%). FEV $1, \mathrm{FVC}_{1} \mathrm{FEV}_{1} / \mathrm{FVC}$ : post bronchodilator measures. ${ }^{*} p \leq 0.05 ;{ }^{* *} p \leq 0.01 ;{ }^{* * *} p \leq 0.001$. Abbreviations: BPD bronchopulmonary dysplasia, $F E V$, forced expiratory volume in $1 \mathrm{~s}, F V C$ forced vital capacity, $L C l$ lung clearance index believe any preterm born subjects with or without BPD declined participation in the study due to not being able to use their pharmacological treatment because the relevant information was collected at inclusion. The procedure did not totally eliminate the bias of having less severely affected subjects in the study but it made it less likely.

The asthma group was well-defined with all subjects sensitized to at least one airborne allergen. They showed an increase in FeNO and blood eosinophils as a sign of ongoing inflammation and were all positive in methacholine challenge test. The asthmatics were all sensitized to pets and some of them also to other airborne allergens such as pollen and house dust mite. As shown in a previous study [34], BPD patients were to lesser extent sensitized to airborne allergens. The preterm born subjects, in particular those adults with a history of BPD were to larger degree positive in methacholine challenge test, as previously demonstrated $[33,35]$. 
The BPD group demonstrated elevated LCI, a sign of small airway disease and air trapping. A low gas diffusing capacity was observed in the BPD group, but also in the preterm group who had normal expiratory flow volumes, confirming earlier findings [31]. We found no pronounced differences between the groups using IOS, opposite to what has been shown in previous studies with children and adolescents $[15,30]$. We speculate that this is related to the relatively older population examined in the current study, as the IOS method may be more sensitive in smaller lung volume range seen in younger individuals.

The BPD group reported less symptoms compared to the asthma group. This is possibly a result of the subjects getting used to a lung function impairment lasting since the neonatal period without larger fluctuations. The asthma group reporting more symptoms might be explained by a disease with alterations in time periods and maybe by inadequately treated asthma.

In agreement to Bozzetto et al. [36], we found that the asthma group demonstrated the lowest PCS scores in SF-36 whereas the BPD group reported similar scores as the healthy controls.There were no differences in PCS scores between the BPD group and the healthy controls. This might be an effect of adaptation (i.e. adjusting the physical activity intensity to the actual lung function to avoid symptoms) as we did not detect any differences in amount of hours of physical activity from the questionnaire. In an earlier study [1], we did not find any significant differences in ergospirometry between the BPDgroups and the preterm group without BPD even if a tendency towards less work capacity was seen with increasing severity of BPD. However, to further evaluate this matter in future studies, exercise testing may be useful.

We also showed that the preterm group displayed similar PCS scores as the asthma group although the preterm group had normal lung function measures which might reflect that many of them suffer from hyper-reactive airways. Opposite to Landry et al. and Bozzetto et al. [33, 36] we found that both the BPD- and preterm groups reported decreased MCS scores compared to healthy controls.

The strength of the current study is that the included cohort was well characterized both regarding lung function and considering subjective, patient-related outcome measures. The preterm born participants in both groups were born in the time period 1992 to 1998 when transition to modern neonatal care occurred, therefor, no clear distinction between "old" and "new" BPD cases can be made. There was also a difference in GA and BW between the preterm born groups, though representative for the whole original cohort except for GA where the subjects in the BPD group was 4 days younger in mean
GA at birth. In our study we were unable to confirm any correlations between being born SGA and impaired lung function which is conflicting with previous studies [31, 37]. We suspect that this could be an effect of small sample size and/or different methods to calculate SGA.

\section{Conclusion}

In summary, we conclude that adults with a history of BPD have obstructive and restrictive lung function impairment, including involvement of small airways. Despite more airway obstruction, the BPD group has less symptoms than those with asthma. The underlying mechanisms for this remain unknown and warrant further investigation. It is important to characterize clinical features, airway symptoms and lung function in subjects born preterm in order to better understand the link between preterm birth and development of chronic lung disease in adulthood. Our study highlights the need for objective assessment of lung health in this group.

\section{Additional files}

Additional file 1: Figure S1. Schematic description of recruitment to the LUNAPRE-study. (PPTX $63 \mathrm{~kb}$ )

Additional file 2: Supplementary methodology. (DOCX $47 \mathrm{~kb}$ ) Additional file 3: Table S1. Symptoms and habits of study participants. (DOCX $20 \mathrm{~kb}$ )

\section{Abbreviations}

ADD: Attention deficit disorder; ADHD: Attention deficit hyperactivity disorder; $A X^{0.5}$ : Square root of the area of reactance; $B M I$ : Body mass index; BPD: Bronchopulmonary dysplasia; COPD: Chronic obstructive lung disease; CPAP: Continuous Positive Airway Pressure; CRP: C-reactive protein; DLCo adj: Diffusing capacity of the lung for Carbon monoxide adjusted for blood haemoglobin; F: Female; FeNO: Fractional exhaled nitric oxide; FEV expiratory volume in $1 \mathrm{~s}$; FVC: Forced vital capacity; GA: Gestational age; GINA: Global Initiative for Asthma; GLI: Global Lung Initiative; ICR: Inter quartile range; LCl: Lung clearance index; M: Male; MCS: Mental component summery; N/A: Not applicable; PCS: Physical component summary; PDA: Patent Ductus Arteriosus; ppb: Parts per billion; $\mathrm{R}_{5-20}$ : Resistance at 5$20 \mathrm{~Hz}$; ROP: Retinopathy of Prematurity; RV: Residual volume; SGA: Small for gestational age; TLC: Total lung capacity; VC: Vital capacity

\section{Acknowledgements}

In particular, we would like to thank all the participating young adults. The authors also thank all the members of the LUNAPRE research team and the research nurses: Margareta Eriksson RN, Christina Ebersjö RN, Margitha Dahl RN, Helene Blomqvist RN, Gunnel de Forest RN and Emma Sundström RN at Sachs' Children and Youth Hospital, Södersjukhuset and Department of Respiratory Medicine \& Allergy, Karolinska University Hospital, Stockholm.

\section{Authors' contributions}

CMS conceived the study. PUB, EBB, GF, MJE, SN, GL, AL, ÅMW, JH, JG, MP, EM and CMS participated in the design and planning of the study. PUB, CMS, MP and GF included study subjects and generated clinical data. PUB, $J H, E M$ and MJE were responsible for lung function tests. PUB and JH carried out the data acquisition and analysis. CMS, AMW, EM and EBB provided financial support and essential infrastructure. PUB, CMS, JH and EM interpreted data. PUB, JH, GF, GL, JG and EBB provided statistical support and assistance in the interpretation of the results. PUB and CMS drafted the manuscript. 
All authors were involved in finalization of the manuscript and approved the submitted version.

\section{Funding}

The Swedish Heart-Lung Foundation, the Swedish Research Council, the King Oscar II Jubilee Foundation, Swedish Asthma and Allergy Foundation, Swedish Respiratory Society, Karolinska Institutet, Hesselman Foundation and through the Regional Agreement on Medical Training and Clinical Research (ALF) between Stockholm County Council and Karolinska Institutet. The sponsors of the study had no role in study design, data collection, data analysis, data interpretation, or writing of the report.

\section{Availability of data and materials}

Anonymized data from the current study is available from the corresponding author on reasonable request.

\section{Ethics approval and consent to participate}

The study was approved by the Regional Ethical Review Board in Stockholm, Sweden, ref:: 201211872-31/4. All participants were fully informed about the purpose and procedures of the study and provided written informed consent prior to enrollment.

\section{Consent for publication}

Not applicable

\section{Competing interests}

PUB, JH, MP, EBB, GF, MJE, SN, JG, GL, AL, AMW, EM and CMS have stated there is no conflict of interest in relation to the study.

\section{Author details}

'Sachs' Children and Youth Hospital, Department of Pediatrics, Södersjukhuset, 11883 Stockholm, Sweden. 'Department of Respiratory Medicine \& Allergy, Karolinska University Hospital, Stockholm, Sweden. ${ }^{3}$ Department of Medicine, Karolinska Institutet, Solna, Stockholm, Sweden. ${ }^{4}$ Institute of Environmental Medicine, Karolinska Institutet, Stockholm, Sweden. ${ }^{5}$ Department of Clinical Science and Education, Södersjukhuset, Karolinska Institutet, Stockholm, Sweden. ${ }^{6}$ Department of Clinical Physiology, Karolinska University Hospital, Stockholm, Sweden. ${ }^{7}$ Department of Molecular Medicine and Surgery, Karolinska Institutet, Stockholm, Sweden. ${ }^{8}$ Thoracic Radiology, Karolinska University Hospital, Stockholm, Sweden.

\section{Received: 13 December 2018 Accepted: 16 May 2019}

Published online: 24 May 2019

\section{References}

1. Global strategy for the diagnosis, management and prevention of COPD, global initiative for chronic obstructive lung disease (GOLD) 2018. Available from: http://goldcopd.org. Accessed Nov 2018

2. Lamprecht B, McBurnie MA, Vollmer WM, Gudmundsson G, Welte T, Nizankowska-Mogilnicka E, Studnicka M, Bateman E, Anto JM, Burney P, et al. COPD in never smokers: results from the population-based burden of obstructive lung disease study. Chest. 2011;139:752-63.

3. Salvi SS, Barnes PJ. Chronic obstructive pulmonary disease in non-smokers Lancet. 2009:374:733-43.

4. Zeng G, Sun B, Zhong N. Non-smoking-related chronic obstructive pulmonary disease: a neglected entity. Respirology. 2012;17:908-12.

5. Postma DS, Bush A, van den Berge M. Risk factors and early origins of chronic obstructive pulmonary disease. Lancet. 2015:385:899-909.

6. Kotecha SJ, Edwards MO, Watkins WJ, Henderson AJ, Paranjothy S, Dunstan FD, Kotecha S. Effect of preterm birth on later FEV1: a systematic review and meta-analysis. Thorax. 2013;68:760-6.

7. Brostrom EB, Akre O, Katz-Salamon M, Jaraj D, Kaijser M. Obstructive pulmonary disease in old age among individuals born preterm. Eur J Epidemiol. 2013;28:79-85.

8. Bolton CE, Bush A, Hurst JR, Kotecha S, McGarvey L. Lung consequences in adults born prematurely. Thorax. 2015;70:574-80

9. McGillick EV, Lock MC, Orgeig S, Morrison JL. Maternal obesity mediated predisposition to respiratory complications at birth and in later life: understanding the implications of the obesogenic intrauterine environment Paediatr Respir Rev. 2017;21:11-8.
10. Duijts L, Reiss IK, Brusselle $G$, de Jongste JC. Early origins of chronic obstructive lung diseases across the life course. Eur J Epidemiol. 2014;29:871-85.

11. Stocks J, Sonnappa S. Early life influences on the development of chronic obstructive pulmonary disease. Ther Adv Respir Dis. 2013;7:161-73.

12. Walsh MC, Wilson-Costello D, Zadell A, Newman N, Fanaroff A. Safety, reliability, and validity of a physiologic definition of bronchopulmonary dysplasia. J Perinatol. 2003;23:451-6.

13. Ghanta S, Leeman KT, Christou H. An update on pharmacologic approaches to bronchopulmonary dysplasia. Semin Perinatol. 2013;37:115-23.

14. GINA: Global strategy for asthma management and prevention (updated 2017): Global Initiative for Asthma (GINA). 2017.http://www.ginasthma.org. Accessed Nov 2018.

15. Brostrom EB, Thunqvist P, Adenfelt G, Borling E, Katz-Salamon M. Obstructive lung disease in children with mild to severe BPD. Respir Med. 2010;104:362-70

16. Jobe AH, Bancalari E. Bronchopulmonary dysplasia. Am J Respir Crit Care Med. 2001;163:1723-9.

17. Marsal K, Persson PH, Larsen T, Lilja H, Selbing A, Sultan B. Intrauterine growth curves based on ultrasonically estimated foetal weights. Acta Paediatr. 1996:85:843-8.

18. Sullivan M, Karlsson J, Ware JE Jr. The Swedish SF-36 health survey--I. evaluation of data quality, scaling assumptions, reliability and construct validity across general populations in Sweden. Soc Sci Med. 1995;41:1349-58.

19. Engstrom CP, Persson LO, Larsson S, Sullivan M. Reliability and validity of a Swedish version of the St George's respiratory questionnaire. Eur Respir J. 1998;11:61-6.

20. Pellegrino R, Viegi G, Brusasco V, Crapo RO, Burgos F, Casaburi R, Coates A, van der Grinten CP, Gustafsson P. Hankinson J, et al. Interpretative strategies for lung function tests. Eur Respir J. 2005;26:948-68.

21. Miller MR, Hankinson J, Brusasco V, Burgos F, Casaburi R, Coates A, Crapo R, Enright $\mathrm{P}$, van der Grinten CPM, Gustafsson P, et al. Standardisation of spirometry. Eur Respir J. 2005;26:319-38.

22. Nieminen MM, Lahdensuo A, Kellomaeki L, Karvonen J, Muittari A. Methacholine bronchial challenge using a dosimeter with controlled tidal breathing. Thorax. 1988:43:896-900.

23. Robinson PD, Latzin P, Verbanck S, Hall GL, Horsley A, Gappa M, Thamrin C, Arets $\mathrm{HG}$, Aurora $\mathrm{P}$, Fuchs $\mathrm{SI}$, et al. Consensus statement for inert gas washout measurement using multiple- and single- breath tests. Eur Respir J. 2013:41:507-22.

24. ATS/ERS recommendations for standardized procedures for the online and offline measurement of exhaled lower respiratory nitric oxide and nasal nitric oxide, 2005. Am J Respir Crit Care Med. 2005;171:912-30. PMID: 15817806. https://www-atsjournals-org.sll.idm.oclc.org/doi/full/10.1164/rccm. 200406-710ST.

25. Quanjer PH, Stanojevic S, Cole TJ, Baur X, Hall GL, Culver BH, Enright PL, Hankinson JL, Ip MSM, Zheng JP, et al. Multi-ethnic reference values for spirometry for the 3-95-yr age range: the global lung function 2012 equations. Eur Respir J. 2012:40:1324-43.

26. Bottai M, Cai B, McKeown RE. Logistic quantile regression for bounded outcomes. Stat Med. 2010:29:309-17.

27. Mosca F, Colnaghi M, Fumagalli M. BPD: old and new problems. J Matern Fetal Neonatal Med. 2011;24(Suppl 1):80-2.

28. Northway WH Jr, Rosan RC, Porter DY. Pulmonary disease following respirator therapy of hyaline-membrane disease. Bronchopulmonary dysplasia. N Engl J Med. 1967;276:357-68

29. Baker CD, Alvira CM. Disrupted lung development and bronchopulmonary dysplasia: opportunities for lung repair and regeneration. Curr Opin Pediatr. 2014;26:306-14.

30. Um-Bergstrom $P$, Hallberg J, Thunqvist $P$, Berggren-Brostrom $E$, Anderson $M$, Adenfelt G, Lilja G, Ferrara G, Skold CM, Melen E. Lung function development after preterm birth in relation to severity of bronchopulmonary dysplasia. BMC Pulm Med. 2017;17:97.

31. Caskey S, Gough A, Rowan S, Gillespie S, Clarke J, Riley M, Megarry J, Nicholls P, Patterson C, Halliday HL, et al. Structural and functional lung impairment in adult survivors of bronchopulmonary dysplasia. Ann Am Thorac Soc. 2016;13:1262-70.

32. Gibson AM, Reddington C, McBride L, Callanan C, Robertson C, Doyle LW. Lung function in adult survivors of very low birth weight, with and without bronchopulmonary dysplasia. Pediatr Pulmonol. 2015:50:987-94.

33. Landry JS, Tremblay GM, Li PZ, Wong C, Benedetti A, Taivassalo T. Lung function and bronchial Hyperresponsiveness in adults born prematurely. A cohort study. Ann Am Thorac Soc. 2016;13:17-24. 
34. Siltanen M, Kajosaari M, Pohjavuori M, Savilahti E. Prematurity at birth reduces the long-term risk of atopy. J Allergy Clin Immunol. 2001;107: 229-34.

35. Vollsæter M, Clemm HH, Satrell E, Eide GE, Røksund OD, Markestad T, Halvorsen T. Adult respiratory outcomes of extreme preterm birth. A regional cohort study. Ann Am Thorac Soc. 2015;12(3):313-22.

36. Bozzetto S, Carraro S, Tomasi L, Berardi M, Zanconato S, Baraldi E. Healthrelated quality of life in adolescent survivors of bronchopulmonary dysplasia. Respirology. 2016;21:1113-7.

37. Bose C, Van Marter LJ, Laughon M, O'Shea TM, Allred EN, Karna P, Ehrenkranz RA, Boggess K, Leviton A. Fetal growth restriction and chronic lung disease among infants born before the 28th week of gestation. Pediatrics. 2009;124:e450-8.

\section{Publisher's Note}

Springer Nature remains neutral with regard to jurisdictional claims in published maps and institutional affiliations.

Ready to submit your research? Choose BMC and benefit from:

- fast, convenient online submission

- thorough peer review by experienced researchers in your field

- rapid publication on acceptance

- support for research data, including large and complex data types

- gold Open Access which fosters wider collaboration and increased citations

- maximum visibility for your research: over $100 \mathrm{M}$ website views per year

At BMC, research is always in progress.

Learn more biomedcentral.com/submissions 